\title{
Aikuiskasvatuksen arvolähtökohtien tarkastelua ${ }^{1)}$
}

Tuomisto, Jukka 1988. Aikuiskasvatuksen arvolähtökohtien tarkastelua. Aikuiskasvatus 8, 1, 19-28. - Artikkelin lähtökohtana on kaksi aikuiskasvatuksen keskeistä arvodimensiota: opiskelu välineenä - itseisarvona ja omaehtoisuus - ulkoaohjautuvuus. Aikuiskasvatuksen yleiset arvolähtökohdat perustuvat humanismin perusajatuksille. Vapaa sivistystyö on perustanut toimintansa pitkälti juuri näille ajatuksille. Työelämän koulutuksessa ei arvolähtökohdista ole keskusteltu, vaan ne on johdettu suoraan teknokraattien asettamista tuottavuus- ja tehokkuustavoitteista, jolloin koulutuksesta on tullut pelkkä väline näiden tavoitteiden edistämisessä. Ongelmana on, että osa vapaan sivistystyön ja työelämän koulutuksen piirissä toimivista aikuiskasvattajista noudattaa vain tunnollisesti ja tehokkaasti heille ulkoapäin annettuja arvoja ja tavoitteita pohtimatta itse lainkaan sitä, mitkä nämä arvot ovat ja mihin nüden noudattaminen johtaa.

\section{Tarkastelun lähtökohtia}

Ihmisten omaksumat arvot ohjaavat monella eri tavoin heidän toimintaansa. Ne ilmenevät ihmisten käyttäytymisessä toisaalta sanoina ja lauseina, toisaalta muuna käyttäytymisenä (esim. ajankäyttönä, rahankäyttönä). Ne ovat aina abstraktioita eli ilmiöitä, joita emme voi nähdä. Tarkasti ajatellen tavanomaiset sanontamme 'arvot muuttuvat' tai 'arvot ovat ristiriidassa keskenään' ovat hämäriä ilmauksia. Kysymys on oikeastaan siitä, että joidenkin ilmiöiden tai asioiden arvo meidän ajatuksissamme muuttuu, siis arvostus muuttuu (Hirsjärvi 1985, 79).

Kasvatus on aina kiinteästi arvoihin liittyvä kulttuurin ala. Toisaalta se on arvoja luova, toisaalta arvoja välittävä ja toteuttava instituutio yhteiskunnassa. Arvot ovat mukana kaikessa kasvatustoimintaa koskevassa yhteiskunnallisessa päätöksenteossa. Kasvatustieteessä erityisesti tavoitteenasettelu ja eettisen alueen kysymykset ovat arvoihin sidoksissa. (emt. 176.)

Koulukasvatuksessa on ensisijaisesti kysymys vallitsevan, yleisesti hyväksytyn arvojärjestelmän opettamisesta ja välittämisestä lapsille ja nuorille, kun taas aikuiskasvatuksessa tulisi tämän lisäksi pyrkiä myös arvojen kriittiseen arviointiin ja niiden uudistamiseen.

\footnotetext{
1) Perustuu Aikuiskoulutuksen arvot ja tavoitteet rakennemuutoksen keskellä -seminaarissa 18.3 .1988 pidettyyn alustukseen.
}

Käytännössä koulu- ja aikuiskasvatusjärjestelmän asema ja tehtävät arvojen välittämisessä ja uudistamisessa eivät eroa tietystikään näin jyrkästi toisistaan. Esimerkiksi omakohtaisessa arvojen pohdinnassa ja arvojärjestelmän muuttamisessa on ilmeisesti kysymys asteittaisesta prosessista ja mm. itsereflektion valmiuksien vähittäisestä kehittymisestä iän mukana.

Vallitsevien arvojen siirtämiseen tuleville sukupolville osallistuu periaatteessa koko aikuisväestö, mutta nykyisin tässä prosessissa ovat entistä keskeisemmässä asemassa - lähikasvattajien ohella (koti, läheiset viiteryhmät) - erilaisissa tiedonvälitys- ja kasvatustehtävissä toimivat aikuiset. Uusien arvojen tietoiseen pohdintaan ja kehittämiseen heistä osallistuu kuitenkin vain pieni osa, lähinnä kriittistä ja uutta luovaa ajatustyötä harjoittava eliitti. Useimmiten ihmisten arvojärjestelmä muotoutuu varsin spontaanisti, ilman tietoista, älyllistä pohdintaa. On myös huomattava, että tunteilla, emootioilla ja motivaatioprosesseilla on - tietojen ohella - keskeinen asema arvojärjestelmän muotoutumisessa.

Tarkasteluni lähtökohdaksi otan kaksi arvodimensiota, joiden avulla yritän jäsentää aikuiskasvatuksen eri toimintasektoreiden arvolähtökohtia.

\section{Opiskelu välineenä - itseisarvona}

Ensimmäisellä dimensiolla on kysymys siitä, nähdäänkö opiskelu ensisijaisesti välineenä vai itseisarvona. Sen pitäminen pelkästään 
välineenä merkitsee sitä, että tietoa hankitaan ja itseä kehitetään ainoastaan siitä syystä, että opiskelulla pyritään joihinkin muihin arvokkaampina pidettyihin tavoitteisiin, esimerkiksi yhteiskunnan yleisen hyvinvoinnin jatkuvaan kohottamiseen, organisaation tehokkuuden ja tuottavuuden lisäämiseen tai yksilön elintason parantamiseen. (Hirsjärvi 1985, 79-80.)

Opiskelun ymmärtäminen itseisarvona taas merkitsee sitä, että sen katsotaan olevan arvo sinänsä. Toiminnan lähtökohtana on pyrkimys tällöin pelkästään ihmisen persoonallisuuden kaikenpuoliseen ja laaja-alaiseen kehittämiseen.

Akateemikko Georg H. von Wright tekee eron tiedon välinearvon ja (tiedon) elämänmuodon välille. Edellinen ei missään tapauksessa hänen mielestään riitä. Tiedolla elämänmuotona hän tarkoittaa jatkuvaa pyrkimystä oppimiseen ja ymmärtämiseen oppimisen ja ymmärtämisen itsensä vuoksi, ilman mitään muita päämääriä. Hän varoittaa kuitenkin tietojen lisäämisen ja erikoistumisen liiallisesta tavoittelemisesta, koska ihmisellä on velvollisuuksia myös perhettään, valtiota ja hädänalaisia lähimmäisiään kohtaan. (von Wright 1981, 56.)

Jotkut asiat voivat olla meille arvokkaita sinänsä, ts. emme tavoittele niiden avulla enää mitään muita asioita tai asiantiloja. Tässä tapauksessa voidaan sanoa, että näillä asioilla tai ilmiöillä on itseisarvo. Yhteiskuntamme yksi perustavimpia arvoja on käsitys ihmiselämän pyhyydestä. Se on arvo, joka ei millään lailla ole riippuvainen yksilön laadusta tai hänen hyödyllisyydestään yhteisössä. Mm. YK:n ihmisoikeuksien ja lapsen oikeuksien julistus sisältää tällaisia itseisarvoa kuvastavia periaatteita ja asioita.

\section{Omaehtoisuus - ulkoaohjautuvuus}

Toinen aikuiskasvatuksen keskeisistä dimensioista on omaehtoisuus - ulkoaohjautuvuus. Monet alan teoreetikot ovat olleet sitä mieltä, että aikuiskasvatuksen tulisi olla aina ihmisten oma- ja vapaaehtoista toimintaa. Tämän mukaan ihmisten tulee saada itse päättää toiminnan arvoista ja tavoitteista. Toisena ääripäänä tällä dimensiolla on hallitsevan luokan arvoje.1 opettaminen ja kuuliaisten kansalaisten kasvattaminen niin, ettei yhteiskunnan legitiimejä arvoja aseteta kyseenalaisiksi. Tällöin toiminta on ulkoaohjattua, eikä se sisällä kriittistä ja omakohtaista vallitsevien arvojen pohdiskelua. Lasten ja nuorten kasvatuksessa lähdetään yleensä vallitsevan yhteiskunnan arvojen opettamisesta, kun taas aikuisten katsotaan olevan kehityspsykologisesti jo sellaisessa vaiheessa, että heidän pitäisi kyetä pohtimaan arvoja itsenäisesti ja kriittisesti.

Toiminnan ulkoaohjaaminen on yleistä tota- litaarisissa yhteiskunnissa. Sen sijaan demokraattisissa yhteisöissä lähdetään enemmän tai vähemmän siitä, että kasvatuksen tulisi pyrkiä myös yksilön itsetajuisuuden ja minätietoisuuden herättämiseen. Harva $(1965,158)$ nimittää tätä personalisaatioksi. Hän näkee sosialisaation (yhteiskuntaan sopeuttamisen) ja personalisaation yhtenä kasvatuksen formaalisena päämääränä ja toteaa, että se missä määrin näihin kumpaankin pyritään, vaihtelee suuresti kulttuureista ja yksittäisistä kasvattajista riippuen (emt.). Harva näkee personalisaation pitkälti sosialisaation vastakohtana, individualistisena pyrkimyksenä "itsensätoteuttamiseen.

Weckroth näkee asian selvästi toisin. Hänen mukaansa ihminen on persoonallisuus sellaisissa tilanteissa, joissa hänen subjektiviteettinsa on osa sosiaalista subjektiviteettia eli tilanteissa, joissa 'minä' lomittuu 'meihin'. Tämän lomittumisen edellytys on paitsi ajatteleminen, muistaminen, havaitseminen ja tahtominen, myös että 'me' tiedämme, mitä olemme tekemässä. Tämä tieto on Weckrothin mukaan yhtä kuin niin sanottu inhimillinen tietoisuus. (Weckroth 1988, 87.)

Kuvio 1. Aikuiskasvatuksen keskeiset arvodimensiot

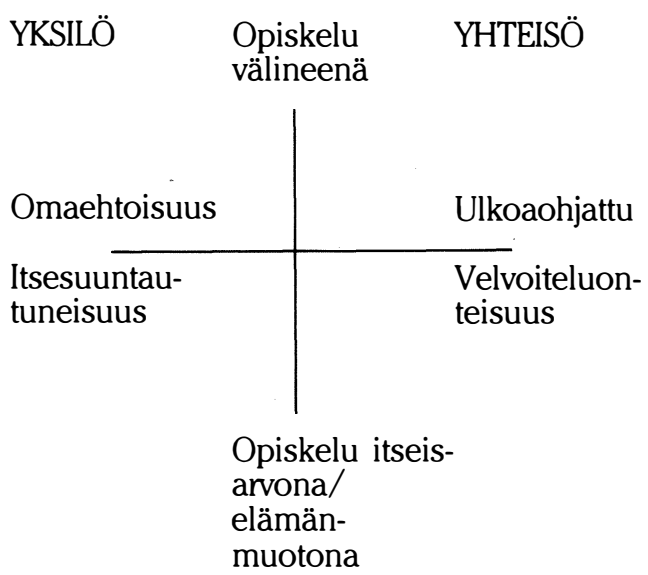

Kun seuraavassa yritetään hahmotella aikuiskasvatuksen arvoja sen eri sektoreilla, niin tarkastelun pohjana ovat kuviossa esitetyt arvodimensiot. Tällöin on kuitenkin muistettava, että aikuiskasvatuksen arvot ja käytännön todellisuus eivät vastaa välttämättä toisiaan. Tästä syystä artikkelissa pyritään ainakin joiltakin osin analysoimaan, missä määrin näitä eroja esiintyy, mutta kovin syvälliseen analyysiin ei näin lyhyessä esityksessä ole mahdollista päästä. Asia vaatisi selvästikin tarkempaa tutkimusta. 


\section{Aikuiskasvatuksen arvot}

On selvää, että aikuiskasvatuksen piirissä on havaittavissa hyvin monenlaisia, ristiriitaisiakin arvoja. Aikuiskasvatuksen yleinen arvofilosofia on kirjattu hallinnon kielellä aikuiskasvatuksen lainsäädäntöön, sitä valmistelleiden komiteoiden mietintöihin sekä opetusministeriön ja kouluhallituksen kannanottoihin. Tästä materiaalista käy ainakin jossain määrin ilmi, minkälaiseen arvofilosofiaan valtio edellyttää aikuiskasvattajien toiminnassaan nojautuvan. (Harva 1980, 9.)

Suomessa aikuiskasvatuksen kokonaisvaltainen valtiollinen suunnittelu alkoi 1970-luvun alussa, jolloin keskeisessä asemassa oli tietysti Aikuiskoulutuskomitea, joka pyrki täsmentämään oman tavoitteenasettelunsa arvoperusteita I osamietinnössään (Kom.miet. 1971:29, 26-27). Se totesi, että koulutuspolitiikan peruslähtökohdaksi on asetettava yksilön henkinen kasvu ja hänen oikeutensa kehittymismahdollisuuksiensa toteuttamiseen ja omaleimaiseen kokonaispersoonallisuuden muotoamiseen. Tältä pohjalta komitea esitti kaksi perusarvoa, joiden tulisi sen mielestä olla suunnittelutyön pohjana.

Ensimmäiseksi perusarvoksi komitea nimesi humaanisuuden, ihmisyyden ja totesi, että sen ehkä yleisesti tunnetuin muotoilu sisältyy YK:n ihmisoikeuksien julistukseen. Sen mukaan koulutusjärjestelmän kaikilla asteilla ja kaikissa muodoissa on pyrittävä edistämään ihmisten valmiutta kunnioittaa toistensa ihmisarvoa, ihmisoikeuksia ja perusvapauksia. Komitean mielestä aktiivinen humaanisuuden perusarvon toteuttaminen merkitsee määrätietoista asettumista ihmisyyttä uhkaavia voimia vastaan ja koko ihmiskuntaan ulottuvan kohtalonyhteyden ja yhteisvastuun tiedostamista.

Toisena perusarvona komitea mainitsee demokraattisen yhteiskuntakäsityksen, johon komitean mielestä sisältyy kansalaisten tasaarvon vaatimus.

On helppo havaita, että ensimmäinen perısarvo liittyy humanismin toteuttamisen individualistiseen aspektiin, kun taas toisessa tulee esiin ihmisen asema yhteiskunnassa, eli humanismin sosiaalinen aspekti. Näitä humanismin eri näkökulmia ei voi erottaa jisistaan. Molempien tulee olla mukana kaikessa aikuiskasvatuksen suunnittelussa. Unescon vuonna 1979 Suomeksi julkaistussa "Aikuiskasvatussuosituksessa" on lähdetty näistä samoista lähtökohdista. (Ks. tarkemmin Aikuiskasvatussuositus. Suomen Unesco-toimikunta, Helsinki 1979.)

Kun aikuiskasvatuksessa on näin virallisella taholla vannottu humanismin nimeen, niin on syytä tarkastella hieman tarkemmin, mitä hu- manistinen ihmiskäsitys oikein käytännössä merkitsee ja miten humanistiset ajatukset ovat välittyneet aikuiskasvatuksen käytäntöön. Lähtökohdaksi otan akateemikko Georg H. von Wrightin kirjassaan (1981) "Humanismi elämänasenteena" esittämät humanismin tunnuspiirteet.

Hänen mukaansa humanismi tarkoitti alkujaan italialaisen oppineiden yhteisön jäsentä, joka keskiajan lopulla löysi jälleen antiikin sivistyksen ja omaksui siitä ihanteita omalle ajalleen. Sanan laajemmassa merkityksessä voimme kuitenkin humanismilla tarkoittaa mielenlaatua ja elämänkatsomusta, jolla on omat psykologiset tunnusmerkkinsä. Ne ovat (von Wright 1981, 16-18):

1) Humanismin tärkein tuntomerkki on, kuten jo nimikin osoittaa ihmisen kunnioittaminen. Ihmisen kaikista luomuksista tärkein on ihminen itse. Yksilön kehitys täydellisyyden ihannetta kohti on lopullinen päämäärä, johon ihmisen kaiken yksilöllisen ja yhteisen ponnistelun tulee pyrkiä.

Aikuiskasvatuksessa ihmisarvon tunnustaminen on merkinnyt mm. vaatimusta sivistyksellisestä tasa-arvosta. On vaadittu, että kaikille on annettava mahdollisuus itsensä kaikinpuoliseen kehittämiseen opiskelun avulla. Tämä vaatimus sisältyi jo Aikuiskoulutuskomitean I osamietintöön ja myöhemmin mm. valtioneuvoston vuonna 1978 antamaan "periaatepäätökseen". Tämän tavoitteen toteuttamisessa ei ole edistytty kuitenkaan kovinkaan hyvin.

2) Humanismin täydellisyysihanne on sivistynyt ihminen, joka tunnustaa totuuden itseisarvon kaikkia auktoriteetteja korkeammaksi. Tämän toteaminen on välttämätöntä, jotta ensimmäisessä kohdassa mainittua individualismia ei käytettäisi peitenimenä pyrkimyksille, jotka kenties ovat täysin humanismin vastaisia.

Aikuiskasvatuksessa tämä näkökohta on ilmennyt mm. siten, että on korostettu sivistyksen merkitystä yksilön kokonaispersoonallisuuden kannalta. Tähän liittyy itseisarvoisen opiskelun merkityksen korostaminen. Tätä painotti aikoinaan jo Zachris Castrén tunnetussa vapaan kansansivistystyön kehittämistä koskevassa komiteanmietinnössään (Castrén 1929, 121). Varhaisemman kansansivistystyön "tieteellisyys-" tai vaatimattomammin ilmaistuna "tieteenomaisuusihannetta" voidaan pitää pyrkimyksenä totuuteen. Ihanteena pidettiin asioiden sisäistettyä oppimista, eikä vain niiden ulkoa oppimista.

3) Humanismille on ominaista, että se pitää sivistystä kokonaisuutena, jakamattomana. Tiedot ja taidot muuttuvat sivistykseksi vasta kasvattaessaan ihmisen koko ajattelussaan ja toiminnassaan ilmentämään laajakatseisuutta, objektiivisuutta ja oikeami lisyyttä, jotka johtuvat totuuden vaatimuksesta. 
Varsinkin aikaisemmin korostettiin, ettei vain ihmisen jonkin puolen kehittäminen riitä, vaan tarvitaan kokonaispersoonallisuuden kehittämistä. Tämä ilmeni mm. Harvan kirjoituksissa, joissa hän jakoi sivistyksen perustavaan yleissivistykseen, ammattisivistykseen ja korkeampaan yleissivistykseen. Viimeksi mainittua hän piti aikuiskasvatuksen varsinaisena tavoitteena, vaikka toteaakin, että aikuiskasvatuksella on tehtäviä kaikilla mainituilla alueilla. (Harva 1958, 44.)

Kiistoissa aikuiskasvatuksen peruskäsitteestä (kansanvalistus/kansansivistys; sivistystyö/ aikuiskasvatus; aikuiskasvatus/aikuiskoulutus) on taitettu peistä ainakin osittain juuri aikuiskasvatuksen laaja-alaisuudesta versus kapea-alaisuudesta. Tähän humanismin tunnuspiirteeseen sisältyy myös näkemys siitä, että opiskelu saa merkityksensä vasta sosiaalisessa kanssakäymisessä ja toiminnassa.

4) Ihmisen kunnioittaminen edellyttää tietynlaista näkemystä valtiosta ja yhteiskuntaelämästä. Ihmistä ei tulisi valtiollistaa, vaan päinvastoin valtio tulisi inhimillistää. Ihminen, jonka humanismi pyrkii luomaan, voi syntyä vain jos hän on vapaa ulkopuolisesta pakosta. Tämän vapauden määrän mittaamisesta voidaan olla eri mieltä. Joka tapauksessa on selvää, että ihmisen vapautuminen edellyttää aina jonkinlaista sosiaalista yhteisöä tai organisaatiota, joka taas merkitsee aina myös jonkinasteista vapauden menettämistä. Jos tämä kuitenkin turvaa ihmiselle jossakin muussa suhteessa turvallisemman ja vapaamman elämän, niin tätä vapaudenmenetystä ei koeta välttämättä pahana asiana. Humanismia ei voida siis tarkastella vain individualistisesta näkökulmasta, vaan siihen sisältyy aina myös ihmisen sosiaalinen puoli. Humanismin toteutuminen on mahdollista ainoastaan sosiaalisessa yhteisössä. Voidaan sanoa, että yksilön rajoittamaton vapaus ei voi olla itsetarkoitus, eikä edes keino johonkin parempaan pyrittäessä.

Aikuiskasvatus perustui varsinkin alkuaikoina siihen Snellmanin ajatukseen, että "sivistyksen yleisyys on nykyaikaisen yhteiskunnan ainoa varma perustus" (Mikkonen 1943, 62). Kansalaiskasvatus on ollut aina keskeinen osa aikuiskasvatusta, vaikka se onkin saanut eri aikoina erilaisia ilmenemismuotoja. Tänä päivänä se näkyy selvimmin järjestömuotoisessa sivistystyössä. Tähän kohtaan liittyy tietysti myös kysymys kansalaisten ja valtiovallan suhteesta, eli missä määrin aikuiskasvatuksen tulisi olla ihmisten omaehtoista toimintaa ja mikä tulisi olla valtiovallan tehtävä tässä toiminnassa. Vapaan sivistystyön osalta Z. Castrén asetti itsemääräämisen periaatteen olennaiseksi osaksi kansansivistystyön identiteettiä. Mallina hänellä oli Englannin "The 1919 Report" (Final Report 1919). Sen mukaan aikuiskasvatuksen organisaatioilla on oltava vapaus päättää toimintansa tavoitteista, sisällöis- tä ja muodoista valtionavun ehtojen asettamissa väljissä puitteissa (ks. Alanen 1986, 61).

Työelämän koulutuksen kohdalla tämä itsemääräämisperiaate ei nähdäkseni toimi samalla tavoin, vaan siellä tavoitteet asetetaan paljolti yhteiskunnan tuotantotoiminnan tarpeista käsin (esim. työllisyyskoulutus). Vaikka yksilö joutuu tällöin olosuhteiden pakosta luopumaan tietyssä määrin itsemääräämisestään, niin hän tekee sen yleensä vapaaehtoisesti oman toimeentulonsa turvaamiseksi. Pitäisi kuitenkin tarkemmin pohtia, milloin tämä yhteiskunnan "holhoaminen" on todella tarpeellista ja milloin siinä mennään liian pitkälle. Voidaan tietysti perustellusti myös kysyä, voidaanko toisenlaisessa historiallisessa tilanteessa ilmaistua periaatetta soveltaa lainkaan nykyiseen työelämän koulutukseen.

5) Vapauden periaatteiden tunnustaminen. Vapauden tiettyjä perusperiaatteita ei voida kieltää kieltämättä samalla humanismia. Muuan tällainen vapaus on ajatuksen- ja sananvapaus. Ihmisen estäminen lausumasta julki ajatuksiaan on kaikissa tapauksissa vääryys. Jos kielletty ajatus on tosi, mitä mahdollisuutta ei voida koskaan jättää huomiotta, niin riistämme näin muilta tilaisuuden vaihtaa väärät mielipiteensä oikeisiin. Jos se taas on väärä, estämme erehdystä vastaan taistelemalla henkilöä pääsemästä selvempään käsitykseen totuudesta. Tämä näkökohta on vähintään yhtä tärkeä kuin ensimmäinen. Totuuden todellinen vihollinen on dogmatismi, ei suinkaan epäily.

Aikuisopetuksessa tämä näkökohta merkitsee mielipiteen ilmaisun vapautta ja tietynlaista arvopluralismia sekä sellaisia opetusjärjestelyjä, jotka mahdollistavat opiskelijoiden aktiivisen osallistumisen (esim. erilaiset ryhmätyömuodot).

Tämän vuosisadan alkupuolella aikuiskasvatuksessa siirryttiin "kansanvalistuksesta" "kansansivistykseen". Tätä käänteentekevää vaihetta on käsitelty mm. eräässä Työläisopiskelijalehden numerossa (ilman kirjoittajan nimeä). Artikkelissa todetaan, että kansanvalistustyö - jota nimitystä käytettiin aikaisemmin - tyytyi vain ylhäältäpäin jakamaan tietoja ja valmiita totuuksia. Nykyaikaisempana terminä artikkelissa pidetään kansansivistystyötä, joka kirjoittajan mukaan ohjaa voimakkaasti omatoimisuuteen ja kriittiseen tiedonetsintään (Työläisopiskelija 9/ 1929). Myöhemmin myös Ville Lehtola on ansiokkaasti käsitellyt tätä samaa problematiikkaa artikkelissaan "Julistus ja epäily vapaassa kansansivistystyössä" (1937). "Julistuksella" hän tarkoittaa valmiiden oppien opettamista (julistamista), kun taas "epäilyllä" hän tarkoittaa kriittistä ja omaehtoista tiedonetsintää. Hän pitää jälkimmäistä lähestymistapaa vapaalle sivistystyölle sopivampana. 
Aikuiskasvatuksen kansainvälisissä julkaisuissa on kirjoitettu viime aikoina paljon aikuisten itsesuuntautuneesta oppimisessa (selfdirected adult learning). Aikaisemmin sitä pidettiin varsin kritiikittömästi opiskelun ihannelähtökohtana, johon kaiken aikuisopiskelun pitäisi perustua. Viimeaikaisissa tutkimuksissa on kuitenkin havaittu, että kyky itsesuuntautuneeseen oppimiseen vaihtelee mm. koulutustasosta ja persoonallisuuden rakenteesta johtuen. Käyty keskustelu on täsmentänyt itsesuuntautuneen opiskelun rajoja ja mahdollisuuksia (ks. esim. Brookfield 1984; Brockett 1985; Caffarella \& O’Donnel 1987; Borgström 1985).

Edellä on esitelty humanismin tunnuspiirteitä hyvin yleisellä tasolla. Seuraavassa tarkastellaan hieman täsmällisemmin, minkälaisille arvoille vapaa sivistystyö ja työelämän koulutus on toimintansa rakentanut.

\subsection{Vapaa sivistystyö}

Lienee tarpeetonta todeta, että edellä esitetyt humanistiset tunnuspiirteet ovat olleet pitkälti ohjenuorana vapaan sivistystyön teoreetikkojen ajatuksissa, vaikka näitä periaatteita ei olekaan aina kovin selkeästi muotoiltu.

\section{Ilmaistut arvot...}

Alanen (1986) on analysoinut vapaan sivistystyön tehtäväkäsitystä tutkimuksessaan "Sivistysjärjestöjen tehtäväkuvan muuttuminen". Hänen mukaansa vapaan sivistystyön perinteinen tehtäväkäsitys koostuu seuraavista viidestä kehysnormista:

1) Kokonaispersoonallisuuden kehittäminen. Tähän sisältyy persoonallisuuden kokonaisvaltaisen (tiedollinen, emotionaalinen ja moraalinen) kehittäminen, laaja-alainen kansalaissisivistys sekä yksilöllisten taipumusten ja harrastusten kehittäminen.

2) Omaehtoisuus. Tähän sisältyy ajatus aikuiskasvatuksesta ihmisten "itsekasvatuspyrkimysten" edistäjänä ja aikuisten omaehtoisesta opinnollisesta harrastuksesta.

3) Opinnollisuus. Tämän normin mukaan sivistystyön on oltava suunnitelmallisesti etenevää ja kokonaisuuksiksi rakentuvaa oppimista.

4) Harrastusopinnot ja yhteiskunnallinen kasvatus tehtäväalana. Varsinkin aikaisemmin katsottiin, että vapaan sivistystyön tehtäväala rajautui lähinnä vapaisiin harrastusopintoihin ja yhteiskunnalliseen kasvatukseen.

5) Itsesäätelyn vapaus. Itsemääräämisen periaate on ollut keskeinen osa vapaan kansansivistystyön identiteettiä. Opetuksen ja muun sivistystyön yleiseen itsesäätelyn periaatteeseen sisältyy ennen muuta aatteellinen vapaus, jonka mukaan erilaiset järjestöt ja aat- teelliset ryhmät voivat toimia "omassa henkisessä ilmapiirissä" ja saada sitä varten valtionapua, kunhan toiminta tapahtuu kasvatuksellisia periaatteita noudattaen. (Alanen 1986, 54-62.)

\section{...ja käytäntö}

Alasen tutkimus kohdistui ainoastaan sivistysjärjestöjen toimintaan, joten arvojen toteutumista voidaan tarkastella ainoastaan niiden osalta. Hänen mukaansa alkuperäinen tehtäväkuva ja niiden traditionaaliset ajattelumuodot ovat suurelta osin säilyneet 1980-luvulle saakka. Julkisivukuva ei kuitenkaan vastaa kovin hyvin reaalikuvaa. Esimerkkinä tästä Alanen mainitsee mm. seuraavat kehitystendenssit: järjestökeskeisyyden voimistuminen, byrokratisoituminen, määrällisten tavoitteiden korostuminen laadullisten kustannuksella, omaehtoisuuden vähentyminen, rekrytoimispohjan kaventuminen, praktisten tavoitteiden korostuminen sekä "pikaopintojen" lisääntyminen (Alanen 1986, 245-246).

Vastaavanlainen kriittinen analyysi paljastaisi varmasti "säröjä" myös kansanopistojen ja kansalaisopistojen julkisivukuvassa. Toiminnan muuttuminen ei tietysti sellaisenaan ole pahasta, mutta sen tulisi perustua tietoiseen harkintaan ja arvovalintoihin, eikä esimerkiksi johonkin mystiseen yhteiskunnalliseen rakennemuutokseen.

\subsection{Työelämän koulutus}

Työelämään liittyvä aikuisten ammatillinen koulutus on kehittynyt melko suunnittelemattomasti ja erillään muusta aikuiskasvatuksesta. Vasta 1970-luvulla tällainen koulutus alettiin tietoisesti lukea aikuiskasvatuksen piiriin kuuluvaksi. Ammatillisen aikuiskoulutuksen arvolähtökohtia ei ole ilmeisesti missään erityisesti pohdittu. Kuitenkin on selvää, että aikuiskasvatuksen yleiset arvot eivät ohjaa ainakaan kovin selkeästi sen kehittämistä.

Mistä sitten johtuu, ettei aikuisten ammatillisen koulutuksen yhteydessä puhuta arvolähtökohdista mitään? Tähän voi löytää ainakin kaksi selitystä.

1) Ammatillisen koulutuksen "arvovapaus". Työelämän koulutuksen arvolähtökohdista ei haluta/kyetä puhumaan. Joskus tuntuu, että erityisesti ammatillisen opetuksen, jota työelämänkin koulutus pääasiassa edustaa, piirissä toimivat ja/tai siihen osallistuvat näyttävät kuvittelevan, että tällainen koulutus on jotenkin objektiivisempaa kuin muu koulutus ja ettei siihen liity mitään arvonäkökohtia. Kysymys on samasta harhasta, joka on nähtävissä teknologian kehittämisen kohdalla. Se nähdään usein jonkin salaisen "mykän pakon" ohjailemaksi ymmärtämättä, että tekninen tutkimustyö ja uusien keksintöjen käytäntöön soveltaminen on 
mitä suurimmassa määrin arvovalintaan perustuvaa. Tämä teknisen alan asiantuntijoiden kykenemättömyys omaa työtään koskevien arvokysymysten havaitsemiseen ja niiden pohdiskeluun johtuu ainakin osittain siitä, ettei arvokysymyksiä tuoda juuri koskaan esille heidän koulutuksessaan. Jokin aika sitten tekn. lis. Satu Hassi puuttui tähän asiaan eräässä päivälehdessä olleessa kirjoituksessaan. Hassin mukaan on merkillistä, että keskustelu arvoista on tabu esimerkiksi teknillisissä korkeakouluissa, joissa koulutettavat ihmiset muuttavat työllään maailmaa ehkäpä enemmän kuin ketkään muut. Hassi kysyy: "Mikä on todellinen seuraus siitä, että arvoja ja päämääriä ei pohdita siellä, missä tiedettä ja tekniikkaa tehdään? Se että noudatetaan niitä arvoja, joita ei tarvitse erikseen perustella. Eli vahvimman arvoja, vallan arvoja, 'arvovapaus' merkitsee toimimista vallan arvoịen mukaan." Hassin mukaan arvoista puhumattomuus ja "arvovapauden" korostaminen merkitsee aina toimimista jonkin hallitsevan teknokraattisen eliitin arvojen mukaisesti. (HS 8.1.1988.) Näyttää siltä, että myös työelämän koulutuksessa on omaksuttu kritiikittömästi tuotantotoimintaa ohjailevan teknokraattisen eliitin arvot. Tämä merkitsee sitä, että työelämän koulutuksen arvot on omaksuttu ulkoapäin kyselemättä ja miettimättä itse niiden järkevyyttä ja käytännön seurauksia.

2) Koulutuksen välineluonne. Puhumattomuus arvoista saattaa johtua myös siitä, että ammatillinen koulutus nähdään usein pelkästään välineenä tuotantotoiminnan yleisempien tavoitteiden saavuttamisessa. Tällöin ei ole syytä puhua ammatillisen koulutuksen omista arvoista. Ammatillisen aikuiskoulutuksen arvoja on tällöin lähdettävä etsimään niistä yleisistä arvoista, jotka ohjaavat enemmän tai vähemmän tietoisesti nykyistä tuotantoelämäämme.

\section{Ristiriitaiset arvot...}

Kuten sosiologi Alan Fox toteaa, vallitsevaa teollista sivilisaatiota ei ole rakennettu silmällä pitäen työn merkitystä ihmiselle, vaan pyrkimyksenä on ollut tuotannon tehokkuus taloudellisen voiton maksimoinniksi eli lyhyesti tehokkuus ja tuottavuus. Työn suunnittelun tavoitteena on ollut lähinnä maksimaalinen tuotos minimaalisin panoksin, eikä ihmisen "itsensätoteuttaminen" työnsä välityksellä. (Lainaus: Gröhn 1983, 65)

Ruotsalainen työelämän tutkija Bertil Gardellin mukaan tapa, jolla työ teollistuneissa yhteiskunnissa on organisoitu, on itse asiassa ristiriidassa inhimillisten perustarpeiden kanssa. Gardellin mukaan leimaa antavana piirteenä esim. Ruotsin työelämässä 1950-luvulta lähtien on ollut pyrkimys mekanisoinnin ja rationalisoinnin avulla lisätä tehokkuutta. Tämä on tapahtunut tietoisesti työn sisällöllisen puolen kustannuksella. Tehokkuusajattelu hyväksyttiin, koska sen nähtiin mahdollistavan resurssien saamisen hyvinvointivaltion ideaalien toteuttamiseksi. Voimakkaasti kärjistäen voitaisiin ehkä sanoa, että monotoniselle, mielenkiinnottomalle ja stressaavalle työlle katsottiin saatavan riittävä kompensaatio kohoavan aineellisen elintason ja lisääntyvän vapaa-ajan myötä. 1960-luvun puolivälissä alkoi kuitenkin ilmetä hankaluuksia: rationalisoinnin seurauksena työpaikkansa menettäneillä alkoi olla vaikeuksia saada uutta työpaikkaa. Mutta vasta 1970-luvulla havahduttiin laajemmin huomaamaan erilaiset terveydelliset ja psykososiaaliset haitat. Tehokkuudesta, joka alun perin oli ollut keino toteuttaa hyvinvointivaltion tavoitteita, olikin vähitellen muodostunut itsetarkoitus. Kaikesta päättäen Gardellin esittämät näkökohdat ovat suuressa määrin yleistettävissä myös Suomen ja yleensä teollistuneiden maiden teolliseen työhön. (Gröhn 1983, 65-66.)

Teknologian kehitys, yhteiskunnan ja työelämän jonkinasteinen demokratisoitumiskehitys sekä kansainvälisen kilpailun kiristyminen on pakottanut tuotantoelämän kehittämisestä vastuussa olevia kiinnittämään huomiota entistä enemmän myös ihmisten henkisten kykyjen kehittämiseen. Yhdysvalloissa alettiin jo 1960luvulla puhua "inhimillisestä pääomasta", koska havaittiin että sen tuottoaste on selvästi suurempi kuin muun pääoman. Tämä pitää paikkansa sekä koko kansantaloudessa että sen yksityistaloudellisessa osassa. Koska koulutus on kannattava investointi, niin sen arvostus on jatkuvasti kohonnut myös talouselämän suunnittelijoiden keskuudessa.

Tämä näkyy mm. viime vuonna julkaistusta ns. Pekkasen komitean mietinnöstä. Oireellisesti komitea otti nimekseen "Tuottava osallistuminen uudistuvassa työelämässä" (Kom. miet. 1987:40). Nimellä komitea halusi korostaa, että ehdotuksilla etsitään ratkaisuja, jotka johtavat sekä yritysten että yksilöiden menestymiseen (lue: taloudelliseen menestykseen) olosuhteiden muuttuessa. Henkilöstön täydennyskoulutuksen kehittämisellä on keskeinen asema komitean uudistusohjelmassa. Komitea katsoo, että työntekijöiden täydennys- ja uudelleenkoulutuksen tarve on tulevalla vuosikymmenellä niin merkittävä, että tämän koulutuksen taloudelliset edellytykset tulee uudistaa perusteellisesti. Komitea tarkastelee koulutusta hyvin yksipuolisesti tuotannollisen toiminnan tehostamisnäkökulmasta, eli välineenä taloudellisen hyvinvoinnin lisäämisessä. Koulutuksen muita arvoja ei tuoda lainkaan esille. Yksilölle täydennyskoulutuksen merkitystä perustellaan myös lähinnä taloudellisen hyödyn näkökulmasta. (emt., 90.)

Mielenkiintoista on, että työelämässä ollaan 
nykyisin niin kiinnostuneita henkilöstön koulutuksesta ja sen itsekehittämispyrkimysten tukemisesta. Ammattipätevyyttä ei ymmärretä enää vain ajankohtaisten tehtävien hallintana, vaan henkilöstöltä edellytetään myös oman ammattialan kehityksen jatkuvaa seuraamista ja kykyä itse aktiivisesti kehittää ammattikäytäntöjään (Virkkunen \& Miettinen 1981, 42-44). Tästä syystä organisaatioteoreetikot ja kasvatusalan asiantuntijat ovat kehitelleet monenlaisia henkilöstön kehittämismetodeja. Mainittakoon näistä esimerkkeinä mm. kehittävä kvalifikaatiotutkimus (Toikka 1984), kannustava työyhteisön kehittäminen (Ruohotie 1985), työelämän pedagogisointi (QWL = Quality of working life and adult education; Cohen-Rosenthal 1982), työn humanisointi ja inhimillisten voimavarojen kehittäminen ( $\mathrm{HRD}=$ Human Resource Development). Nämä moninaiset kehittämispyrkimykset osoittavat, että inhimillisten voimavarojen käyttöön on todella kiinnitetty viime vuosina lisääntyvää huomiota. Sitä missä määrin nämä kehittämispyrkimykset antavat todella henkilöstölle mahdollisuuksia itsesuuntautuneeseen ja omaehtoiseen työnsä kehittämiseen on vaikea arvioida. Ainakin osa kehittämishankkeista perustuu pelkästään organisaatioiden itsekkääseen tehokkuus- ja tuottavuustavoitteeseen, eivätkä ne välttämättä sisällä mitään todellista pyrkimystä työelämän kaikinpuoliseen kehittämiseen ja inhimillisten voimavarojen vapauttamiseen. Olisi tärkeää, että nämä suuntaukset otettaisiin kriittisen tutkimuksen kohteeksi, kuten jo osittain onkin tapahtunut (Julkunen 1986).

\section{...ja käytäntö}

Mitä sitten koulutuksen alistaminen tehokkuuden ja tuottavuuden lisäämisen välineeksi on vaikuttanut työelämän koulutukseen? Kovin tarkkaa tietoa tästä ei ole saatavissa, mutta joitakin yleisiä kehitystrendejä voidaan kuitenkin mainita. Seuraavat havainnot perustuvat teollisuustyönantajien koulutuksesta saatuihin tutkimustuloksiin (Tuomisto 1986), mutta luultavasti ne pitävät paikkansa myös monilla muilla työelämän sektoreilla.

Koska lyhyen tähtäyksen hyöty- ja taloudellisuusajattelu on ohjannut teollisuuden koulutuksen suunnittelua, niin se on pyrkinyt huolehtimaan lähinnä vain välttämättömistä ja ajankohtaisista henkilöstönsä kehittämistarpeista. Tästä on ollut seurauksena mm. työvoiman kvalifikaatioiden polarisoituminen, koulutussisältöjen kapea-alaistuminen ja yksipuolinen erikoistuminen, koulutussuunnittelun lyhytjänteisyys sekä koulutuksen kyvyttömyys vastata ajankohtaisiin kehittämishaasteisiin.

Yritykset ovat kouluttaneet lähinnä tuotannon kehittämisessä avainasemassa olevia henkilöstöryhmiä, eli suunnittelu- ja kehittämistyössä mukana olevia toimihenkilöitä sekä joh-

totehtävissä olevia. Tämä on johtanut kvalifikaatioiden polarisoitumiseen, mikä on tietysti koulutuksellista tasa-arvoa ajatellen ongelma. Näin työnantajien koulutus on vahvistanut entisestään koulutuksellista eriarvoisuutta.

Työnantajien koulutus on nykyisin enimmäkseen varsin kapea-alaista, yrityskohtaista väline- tai erikoiskoulutusta. Laaja-alaisempi ja ammatillisen identiteetin kehittymisen kannalta välttämätön koulutus on vähäistä. Tämä on rajoittanut henkilöstön yleisempiä ammatillisia kehittymismahdollisuuksia ja kokonaispersoonallisuuden kehittymistä.

Koulutuksen rajoittaminen vain yrityksen lyhyen tähtäyksen ja ajankohtaisten tarpeiden tyydyttämiseen on synnyttänyt paljon lyhytkestoista ja usein sirpalemaista koulutusta, jonka hyödyllisyys on asetettu nykyisessä nopean muutoksen vaiheessa yhä useammin kyseenalaiseksi. Koulutus on vain harvoin liitetty selkeästi henkilöstön urallakehittymiseen ja -etenemiseen. Näin se ei ole edistänyt kovinkaan hyvin henkilöstön jatkuvaa ammatillista kasvua.

Yhteenvetona voidaan todeta, että vaikka henkilöstön kehittämisestä onkin paljon puhuttu, niin se on kuitenkin rajattu nykyisin varsin tiukasti yksinomaan yritysten taloudellisen tuottavuuden edistämiseen.

\subsection{Arvot ja opiskelun tavoitteet}

Seuraavassa kuviossa on pyritty havainnollistamaan, miten arvot vaikuttavat opiskelun tavoitteisiin.

Kuvio 2. Aikuiskasvatuksen keskeiset arvodimensiot ja opiskelun tavoitteet

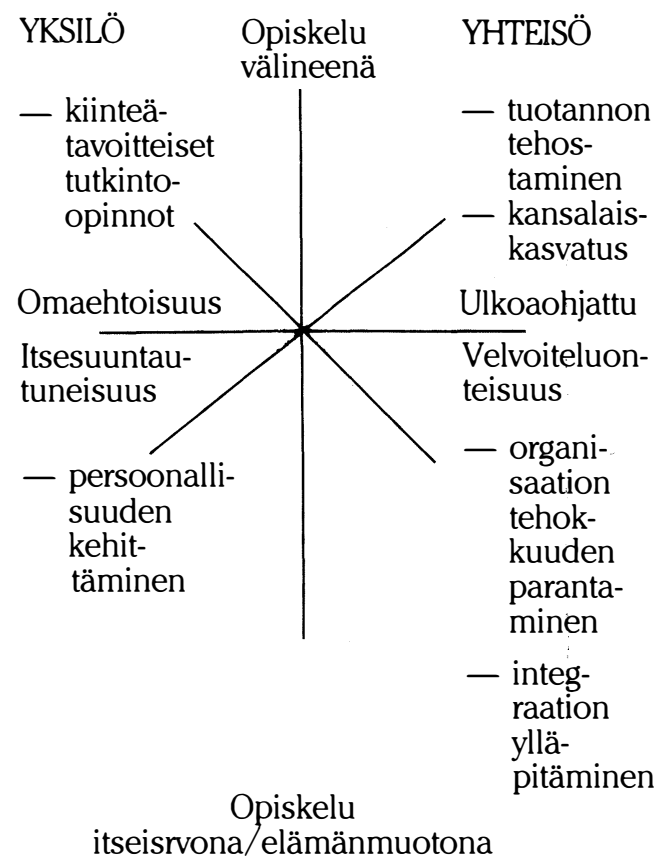


Yksilön omaehtoinen opiskelu voi olla toisaalta persoonallisuuden kehittämiseen tähtäävää harrastusopiskelua tai sellaisten kiinteätavoitteisten tutkinto-opintojen suorittamista, joiden avulla henkilö voi mahdollisesti parantaa asemaansa työelämässä.

Vapaa sivistystyö on perinteisesti nähty vapaaehtoisena opiskeluna. Vaikka opiskelussa ei olekaan ensisijaisesti tähdätty tutkintojen suorittamiseen, niin osa opiskelijoista on asettanut itselleen myös tällaisia tavoitteita. On huomattava, että vapaassa sivistystyössä on ollut aina mukana myös yhteisönäkökulma. Varsinkin kansansivistystyön alkuaikoina oli kansalaiskasvatuksella keskeinen asema.

Oman järjestön tai organisaation tavoitteiden edistäminen on myös aina aikuiskasvatuksessa mukana. Tämä näkyy erityisesti sivistysjärjestöjen toiminnassa. Se missä määrin niiden tulee ohjata kasvatustoimintaansa omista lähtökohdistaan ja pyrkimyksistään ja missä määrin toiminnan taas tulisi tapahtua jäsenistön omilla ehdoilla, on vaikea kysymys. Nykyisin meillä on toisaalta varsin keskusjohtoisesti toimintaansa ohjaavia sivistysjärjestöjä, kun taas toiset pyrkivät mukauttamaan tietoisesti toimintansa jäsenistön muuttuviin tarpeisiin.

Työelämän koulutuksen lähtökohtana ovat pääpainoisesti yhteisölliset arvot. Näitä arvoja säätelevät valtion, kuntien, erilaisten työ- ym. organisaatioiden ja järjestöjen tavoitteet. Koulutustoiminta on ensisijaisesti näiden organisaatioiden tavoitteiden pohjalta suunniteltua. Yhteiskunnallisella tasolla koulutus lähtee työelämän vaatimuksista ja arvoista (mm. täystyöllisyys ja työmarkkinoiden joustavuus). Organisaatiotasolla voidaan erottaa työ- ja muut organisaatiot (esim. erilaiset järjestöt) toisistaan. Työorganisaatioiden tavoitteet ja arvot määräytyvät pääasiassa tehokkuus- ja tuottavuustavoitteista sekä henkilöstön integrointipyrkimyksistä. Tämä supistaa yritysten koulutuksen helposti pelkäksi työelämän kehittämisen välineeksi, jonka koulutuksen tavoitteet asetetaan henkilöstölle ulkoapäin. Vain poikkeustapauksissa (innovaatiotoiminnassa ja tieteellisessä jatkokoulutuksessa) henkilö voi itsenäisesti päättää toimintansa tavoitteista. Tällöinkin hänen tietonsa alistetaan myöhemmin organisaation muiden päättäjien arvioitavaksi.

On selvää, että opiskelijan arvot ja tavoitteet ovat yleensä samansuuntaisia. Joissakin tapauksissa opiskelija voi kuitenkin joutua opiskelemaan myös sellaisia asioita, joita hän ei välttämättä itse arvosta, mutta jotka ovat esim. yrityksen kannalta välttämättömiä. On myös huomattava, että vaikka henkilö korostaa tietynlaisia arvovalintoja, niin hän saattaa ymmärtää ainakin jossakin määrin muunlaisiakin ar- voja. Toisaalta arvot ovat vain harvoilla ihmisillä harmonisessa järjestyksessä keskenään. Tavallisempaa lienee, että ihmiset arvostavat usein myös keskenään ristiriitaisia asioita. Tärkeätä on, että ihmiset tiedostaisivat nämä ristiriidat ja pyrkisivät analysoimaan niitä loogisesti.

\section{Aikuiskasvattajat ja arvot}

Ajateltaessa aikuiskasvattajien ammatillista perusasennoitumista heidät voidaan periaatteessa jakaa kolmeen ryhmään (vrt. Alanen 1985):

1) Aikuiskasvattajat, jotka lähtevät aidosti humanistisesta kasvatusnäkemyksestä, jonka mukaan kaikilla tulee olla mahdollisuus itsensä kaikinpuoliseen kehittämiseen. Koska humanismiin liittyy keskeisenä ajatuksena kriittisyys, niin tästä näkökulmasta aikuiskasvatuksen tulee muodostaa yhteiskuntaa kriittisesti tarkasteleva ja sitä muuttamaan pyrkivä elementti, eli toiminnan tavoitteena tulisi olla ihmisen emansipaation edistäminen. Tällainen aikuiskasvattaja on kiinnostunut todella työstään ja pyrkii aktiivisesti herättämään ihmisissä halua itsensä kehittämiseen ja yhteiskunnan muuttamiseen. Tämä merkitsee yleensä sitä, että aikuiskasvattaja tiedostaa yhteiskunnassa vallitsevat erilaiset työmarkkina-, poliittiset yms. ristiriidat, eikä karta niitä opetuksessakaan. Opetuksen tavoitteena on kuitenkin aina kriittinen totuudenetsintä, eikä esim. jonkin ideologian "pakkosyöttö". Tällainen aikuiskasvattaja on todella huolestunut alistettujen asemasta ja pyrkii aktivoimaan heitä omien etujensa ajamiseen (arvorationaalisuus).

2) Aikuiskasvattajat, jotka näkevät olevansa vain jonkin virallisen tahon ajatusten toimeenpanijoita. He eivät pohdi oman toimintansa arvofilosofisia lähtökohtia, vaan toteuttavat kyselemättä annetun päämäärän arvoperusteita, viisautta tai moraalia (tavoiterationaalisuus). He näkevät yhteiskunnan funktionaalisena konsensusyhteiskuntana. Toimessaan he voivat pyrkiä "tunnolliseen toimenhoitoon" ja "tehokkaaseen palveluun" (Alanen 1985, 136). Säännösten ja järjestyksen orjallinen noudattaminen ei rohkaise oma-aloitteiseen toiminnan kehittämiseen ja kokeiluun.

Tällaiset aikuiskasvattajat ovat kiinnostuneita ainoastaan siitä, että he noudattavat mahdollisimman hyvin annettuja ohjeita ja että osallistumisluvut ovat mahdollisimman suuret. Näyttää siltä, että nimenomaan ammatillisen aikuiskasvatuksen puolella esiintyy tavallista enemmän tällaista ulkoaohjattua, vain teknisiin yksityiskohtiin keskittyvää kasvatusajattelua ja opetusta. 
3) Aikuiskasvattajat, jotka tekevät työtään pelkästään palkan vuoksi. He pyrkivät minimoimaan toimintansa sille tasolle, että se juuri täyttää vaadittavat suoritukset. Jotkut organisaatiot saattavat myös muodostua itsetarkoituksellisiksi, eli koska ne ovat olemassa, ne pyrkivät säilyttämään oman olemassaolonsa, vaikka niillä ei ole enää mitään todellista funktiota. On selvää, ettei tällainen toiminta voi menestyä kovin kauaa.

Edellä olevalla karkealla luokittelulla olen halunnut tuoda esiin sen tosiasian, ettei kaikki aikuiskasvatus ja -opiskelu ole samanarvoista. Jos tuijotetaan vain osallistumislukuihin, pohdiskelematta opetuksen sisältöä, voidaan edistää aivan muita asioita ja arvoja kuin mitkä on perinteisesti asetettu aikuiskasvatuksen tavoitteiksi. Niin kuin koulutusta yleensä, niin myös aikuiskasvatusta voidaan käyttää ihmisten "sopeuttamiseen" ja alistamiseen. Tästä on osoituksena se, että totalitaarisissa järjestelmissä kasvatustoiminta on yleensä varsin keskeisessä asemassa.

Sama vaara on koko ajan vaanimassa myös meidän konsensukseen perustuvissa hyvinvointidemokratioissamme. Tästä syystä on, aina kun puhutaan aikuiskasvatuksen ongelmista, pohdittava myös opetuksen laatuun (sisältöön) liittyviä kysymyksiä. Aikuiskasvatus ei saa olla pelkästään valtaapitävien ajatusten siirtämistä alamaiskansalaisten ajatuksiin, vaan siihen on aina sisällytettävä kriittisyys ja uutta ajattelua luomaan kehittävä pyrkimys.

\section{Yhteiskunnallinen muutos vaatii arvojen arviointia}

Tutkiessaan maassamme vuosina 1956-1975 tapahtunutta koulutuksen kehittämistä Peltonen $(1979,202)$ tuli siihen tulokseen, että tuolloin ilmestyneiden komiteanmietintöjen tavoitteidenasettelussa oli pääpaino sellaisissa arvoissa, jotka läheisesti liittyvät yhteiskunnan taloudelliseen kehitykseen. Sen sijaan arvot, jotka liittyvät sellaisiin elämänalueisiin kuin moraaliin, uskontoon, ihmisten henkilökohtaiseen elämään ja kulttuuriin jäivät taka-alalle. Tarkasteltaessa viime aikaisia aikuiskasvatuksen kehittämisestä laadittuja komitean- ja toimikuntien mietintöjä, voi todeta, että tämä suuntaus jatkuu edelleen entisestään vielä voimistuneena.
On selvää, että tuotantontoiminnan kehittäminen on tärkeätä yleisen hyvinvoinnin ylläpitämiseksi, mutta voi kysyä, eikö tuotannollinen näkökulma ole saanut jo liiaksikin huomiota osakseen muiden elämänalueiden kustannuksella. Tosiasia on, että vapaa-aika on lisääntynyt jatkuvasti, yhä suurempi osa yhteiskunnan kokonaisväestöstä on työelämän ulkopuolella ja jopa työelämässä mukana olevat näkevät usein muut elämänalueet itselleen tärkeämmiksi kuin työn. Tässä tilanteessa olisi koulutuspoliittisen suunnittelun pohjana olevia arvoja pohdittava kokonaan eri näkökulmasta kuin aikaisemmin. Ruotsalainen Gunnar AdlerKarlsson (1983) on painottanut, että koululaitosta ei saisi enää käyttää yksinomaan valmistuspaikkana työelämään, vaan nuorille tulisi opettaa muitakin arvoja kuin protestanttista työnetiikkaa. Olisi korkea aika pohtia, minkälaisia tietoja ja arvoja nykyajan nuoret todella tarvitsevat, kun he aikuistuvat ja siirtyvät aikanaan mahdollisesti työelämän piiriin. On ilmeistä, että työ perinteisessä merkityksessä ei ole heille enää yhtä keskeinen ja tärkeä elämänalue kuin se on ollut aikaisemmille sukupolville. Tämä tullee aikanaan näkymään myös aikuiskasvatuksessa.

Kuten artikkelin alkupuolella totesin, aikuisten asema on yhteiskunnan arvojen uudistamisessa keskeinen. Tämä kuitenkin edellyttää heiltä kykyä ja halukkuutta omien arvojensa jatkuvaan pohdintaan ja uudelleenarviointiin. Tämä voi Harvan mukaan $(1980,21)$ tapahtua seuraavalla tavalla. Ensin tutkimme, ketkä mitäkin mielipidettä kannattavat. Sen jälkeen otamme selvää, mistä lähteestä jokin normi on peräisin ja millä argumenteilla sitä on perusteltu. Pohdimme niitä seurauksia, joita normin johdonmukainen seuraaminen aiheuttaa. Tutkimme, kenen tai minkä ryhmän etujen mukainen tai vastainen normi on ja selvitämme, minkälainen ihmiskäsitys tai elämän- ja maailmankatsomus on moraalisen mielipiteen taustalla. - Tätä arviointimenetelmää tulisi soveltaa sekä nykyiseen vapaan sivistystyön että ammatillisen aikuiskoulutuksen suunnitteluun ja uudistamiseen.

Vain jatkuvasti kehittämällä moraalisen ajattelumme menetelmiä voimme parantaa arvostelukykyämme. Omien arvostuksien jatkuvan pohdiskelun tulisi kuulua jokaisen aikuisen elämään, koska vain tiedostamalla oman toimintansa arvolähtökohdat ja niitä kriittisesti arvioimalla ihminen voi varmistua siitä, että hänen henkinen kehityksensä jatkuu. Makrotasolla tämä merkitsee mahdollisimman avointa ja kriittistä keskustelua nykyisen aikuiskasvatuksen kehittämistyön arvolähtökohdista. 
Adler-Karlsson, Gunnar 1983. Koulu — pysäköimispaikka tarpeettomille vai tie sisäiseen avartumiseen. Tammi: Helsinki.

Aikuiskasvatussuositus. Suomen Unesco-toimikunta. Helsinki 1979.

Alanen, Aulis 1986. Sivistysjärjestöjen tehtäväkuvan muuttuminen. Tampereen yliopisto. Aikuis- ja nuorisokasvatuksen laitoksen julkaisuja 23.

Alanen, Aulis 1985. Tehokas palvelu aikuiskasvattajan ammatti-ideaalina. Teoksessa Manni \& Tuomisto (toim.), Humanistin teemojen tuntumassa. Acta Universitatis Tamperensis, ser. A, vol. 196.

Borgström, Lena 1985. Self-directed learning and the reproduction of inequalities. Paper framlagt vid International League for Social Commitment in Adult Education Conference 1985.

Brockett, Ralph 1985. Methodological and substantive issues in the measurement of self-directed learning readiness. Adult Eduction Quarterly, Vol. 36 , number 1, 15-24.

Brookfield, Stephen 1984. Self-Directed adult learning: A critical paradigm. Adult Education Quarterly, Vol. 36, number 2, 59-71.

Caffarella, Rosemary \& O'Donnel, Judith 1987. Selfdirected adult learning: A critical pardigm revisited. Adult Education Quarterly. Vol. 37, number 4, 199-211.

Castrén, Zachris 1929. Valtio ja vapaa kansansivistystyö. Valtioneuvostolle jätetty mietintö. Kansanvalistus- ja kirjastolehti 5-6, 1929.

Cohen-Rosenthal, Edward 1982. Participation as pedagogy: Quality of Working Life and Adult Education. Convergence, Vol. XV, No 1.

Final Report. Adult Education Committee. Ministry of Reconstruction. Command Paper 321, 1919. London.

Forssell, Osmo 1983. Koulutuksen kehittämisnäkymiä. Koulutus, työelämä, talous. Opetusministeriön suunnittelusihteerin julkaisuja 1. Helsinki: Valtion painatuskeskus.

Gröhn, Kari 1983. Työelämän ja ammattien kehityksestä ja näiden yhteyksistä koulutuksen uudistamiseen ja mitoitukseen. Koulutus, työelämä, talous. Opetusministeriön suunnittelusihteeristön julkaisuja 1. Helsinki: Valtion painatuskeskus.
Harva, Urpo 1965. Systemaattinen kasvatustiede. Helsinki: Otava.

Harva, Urpo 1958. Aikuiskasvatus. Johdatus aikuiskasvatuksen teoriaan ja työmuotoihin Suomessa. Helsinki: Otava.

Harva, Urpo 1980. Aikuiskasvattajan arvofilosofia. Aikuiskasvattaja. Vapaan sivistystyön XXIV vuosikija. Juva: WSOY.

Hirsjärvi, Sirkka 1985. Johdatus kasvatusfilosofiaan. Helsinki: Kinjayhtymä.

Julkunen, Raija 1986. Työprosessit ja pitkät aallot. Tampere: Vastapaino.

Kansansivistystyön käsitesisällön tarkastelua. Työläisopiskelija N:o 9/1929.

Komiteanmietintö 1975:28. Aikuiskoulutuskomitean II osamietintö. Helsinki: Valtion painatuskeskus.

Komiteanmietintö 1987:40. Tuottava osallistuminen työelämässä. Helsinki 1988. Valtion painatuskeskus.

Lehtola, Ville 1937. Julistus ja epäilys vapaassa kansansivistystyössä. Opintotoveri, s. 27-31.

Mikkonen, Wiljo 1943. Snellmanin ajatuksia sivistyksestä ja kouluopetuksesta. Kansanvalistus ja kirjastolehti 3.

Peltonen, Aimo 1979. Koulunuudistuksen ihmiskäsitys ja eettiset periaatteet. Suomalaisen teologisen kirjallisuusseuran julkaisuja 113. Vammala.

Ruohotie, Pekka 1985. Kannustava työyhteisö. Tampereen yliopiston Hämeenlinnan opettajakoulutuslaitos. Julkaisuja N:o 12.

Toikka, Kari 1984. Kehittävä kvalifikaatiotutkimus. Valtion koulutuskeskus, julkaisusarja B n:o 25. Helsinki: Valtion painatuskeskus.

Tuomisto, Jukka 1986. Teollisuuden koulutustehtävien kehittyminen. Acta Universitatis Tamperensis ser. A, vol. 209. Vammala.

Virkkunen, Jaakko \& Miettinen, Reijo 1981. Opetus ja työstä oppiminen henkilöstön kehittämisessä. VKK, julkaisusarja B n:o 14. Helsinki: Valtion painatuskeskus.

Weckroth, Klaus 1988. Toiminnan psykologia. Helsinki: Hanki ja jää.

von Wright, Georg 1981. Humanismi elämänasenteena. Keuruu: Otava. 


\section{AIKUISKASVATUS \\ The Finnish Journal of Adult Education \\ Vol. 8,1/88 \\ ISSN 0358-6197 \\ Summary}

Tuomisto, Jukka 1988: An Inquiry into the Value Bases of Adult Education.

At the basis of this article lie two sets of value antitheses central to adult education:

- study as a means to an end vs. study as a absolute value; and

- study as self-directed leaming vs. study as externally initiated activity. The values at the heart of adult education are founded on the basic principle of humanism. Liberal education has been to a great extent based on precisely these principles, so that self-directive and the intrinsic value of study have in general been central to it. The value bases of vocational training have not been discussed, but they have in practice come from "the outside" from technocratic production and efficiency goals. This training has become a mere means to the reaching of these goals. Even though many adult educators think critically and independently, many others merely attempt conscientiously and efficiently to realize these externally imposed values and goals. In the development of adult education in Finland in recent years the values and goals of productivity have been emphasized. What is now needed is profound critical discussion of what this means in light of the traditional value bases of adult education. 